\title{
Exploring the internal antecedents that prompt consumers' impulsive behaviour in experiential retail contexts
}

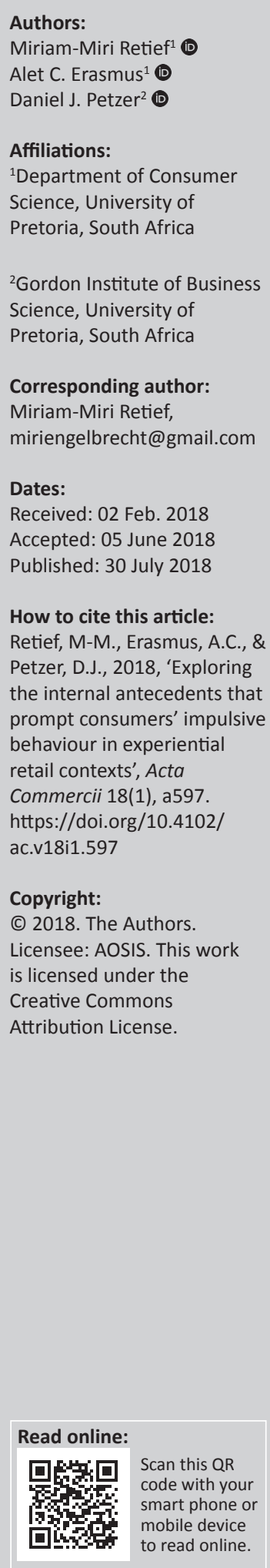

Orientation: Experiential settings are becoming more popular to differentiate conventional brick-and-mortar retailing which now faces fierce competition from multiple other retail platforms.

Research purpose: The study aims to identify and explain the internal driving forces that positively predict consumers' impulsive behaviour in experiential retail settings.

Research design, approach and method: This quantitative investigation entailed a retrospective assessment of consumers' experiences at diverse experiential retailers. An electronic survey approach enabled the collection of 402 usable questionnaires based on a purposive sampling technique whereby a heterogeneous sample of consumers 18 years and above who have visited one of the identified experiential retailers were recruited. Stepwise regression analyses were conducted to test the hypothesised relationships between the independent and dependent variables.

Main findings: Results suggest that consumers' mood and emotions, adventure, gratification and social shopping motives as well as their desire for recreation are conducive to certain impulsive behavioural outcomes, namely irresistible desire creation, impulsive purchases and impulsive participation. A significant finding is that impulsive actions are not necessarily preceded by an irresistible urge. However, the urge to act on impulse is regarded a separate impulsive behavioural outcome.

Practical/managerial implications: Impulsive behaviour should be regarded as a valuable outcome in terms of an understanding of consumers' behaviour in experiential retail contexts. Not only does it offer retailers competitive advantage possibilities but it also constitutes more satisfying experiences for consumers.

Contribution/value-add: A theoretical contribution is made in terms of an integration of literature on experiential retail and impulsive behaviour.

\section{Introduction}

The nature of consumer decisions ranges from simple to very complex, and the time devoted to the decision process will vary accordingly. Consumers' risk perception, the information required to conclude the decision and consumers' confidence to conclude the decision therefore differ considerably from one decision to the next (Zander \& Hamm 2012). Authors have tried to compile a complexity continuum to differentiate products in terms of the complexity associated with particular decisions to explain consumers' behaviour in the marketplace when dealing with different product categories (Erasmus, Donoghue \& Dobbelstein 2014). When discussing differences in the complexity that are associated with different purchase decisions, impulsive decisions are however not accounted for (Erasmus et al. 2014). Per definition, impulsive purchase decisions are made on the spot, without prior meditation or deliberation (Bayley \& Nancarrow 1998; Rook \& Fisher 1995; Saad \& Metawie 2015; Sharma, Sivakumaran \& Marshall 2010).

Impulsive purchases are not necessarily limited to certain product categories, or to low risk, low complexity purchases. In a specific context, a consumer's decision to purchase a commodity on the spot may go beyond rational thought. Depending on the product, a consumer might argue that if an opportunity is lost, it might be impossible to get hold of a particular product again, to enjoy the advantage of the discount, or to pride oneself on owning a unique product that will be admired by others (Baumeister 2002; Hausman 2000; Rook \& Fisher 1995). Impulsive purchases are unique in that they are based on stimulated interest and emotion that may even become 
uncontrollable and overpowering. The subsequent hedonistic desires may then override rational thought and stimulate action, such as to purchase products or participate in activities that a consumer has not considered prior to entering the retailer or venue (Kalla \& Arora 2011). For example, an urge to have fun and to spoil oneself could supersede the functional benefits of the products, denoting internal antecedents as important contributors (Ungerer 2014; Virvilaite, Saladiene \& Žvinklyte 2011).

Impulsive behaviour does not involve any pre-planning or prior information search: it is an immediate behavioural response to an individual's desires (Beatty \& Ferrell 1998; Ungerer 2014) when the individual almost instantaneously reverts to underlying emotional reasoning to act (Amos, Holmes \& Keneson 2014; Silvera, Lavack \& Kropp 2008). Impulsive behaviour occurs after consumers experience an urge which is often irresistible (Beatty \& Ferrel 1998). Rational thought, on the other hand, implies calculative, informed decisions with some understanding of the value of the decisions (Babin \& Harris 2016; Solomon 2007). These decisions include the use of product information, even if it is experience based (Jackson 2005), to enable an evaluation of the possible outcomes and advantages or disadvantages of a purchase decision (Solomon 2007; Van Hamersveld \& De Bont 2007). Only when faced with an overwhelming array of options, a consumer would revert to emotions as a heuristic to facilitate choices (Van Hamersveld \& De Bont 2007).

Because consumers are tempted beyond logical reasoning, one may argue that attempts to evoke impulsive purchases are not ethical. In defence, retailers have come to the realisation that consumers have become more critical of traditional brick-andmortar shopping environments (Marsland 2015; Stops 2013), arguing that consumers appreciate stimulation, and a service scape that excites and entices (Chang 2016). For modern-day consumers, shopping is no longer an activity to solely acquire goods and services. Retail experiences have now become pivotal in terms of purchase decisions (Stops 2013). It is even argued that brick-and-mortar shopping will only be sustainable if it succeeds in providing an environment where consumers' longing for pleasure, fantasy and fun can merge into a memorable experience (Portas 2010; Stops 2013). Experiential retail therefore seems to be the ideal approach to engage consumers in a memorable way (Pine \& Gilmore 2011) through non-instrumental benefits and pleasure unlike traditional retail that predominantly focuses on utilitarian benefits and monetary gains (Fiore \& Kim 2007). Consumer behaviour in experiential retail environments differs from that in traditional retail environments as instead of focusing on the purchase process, experiential retail aims at entertaining consumers. This means that the whole environment instead of merely product-related aspects will contribute in shaping the experience.

This study aims to identify and explain internal driving forces that might prompt consumers' impulsive behaviour in experiential retail settings. Theoretically, this will underpin and enhance an understanding of the antecedents and driving forces that underlie consumers' impulsive behaviour in these contexts. Findings will contribute to the body of theoretical knowledge on consumer behaviour by amalgamating literature on impulsive behaviour with that of experiential retail. Despite the acknowledgement that impulsive behaviour relates to the experiential approach of shopping (Hausman 2000; Mowen 1988), these concepts have not been explored together in the context of experiential retail. To date, several researchers have attended to experiential retail as a differentiation tool to identify principles of the experiential servicescape that could be incorporated by traditional retailers (Gentile, Spiller \& Noci 2007; Plevoets, Petermans \& Van Cleempoel 2010; Senthil, Chandrasekar \& Selvabaskar 2012; Verhoef et al. 2009). Popular theories grounding experiential retail include Pine and Gilmore's (1998) four realms of experiences (entertainment, educational, aesthetic and escapist) that could be used by retailers to design memorable experiences. Although this theory provides an overall guideline that provokes thoughts towards creating certain experience realms within any type of business, there is a lack of specific factors related to each realm. Schmitt (1999) also developed a theory based on strategic experiential modules (SEMs) wherein he explains how attending to consumers' senses, actions, feelings, thoughts and relatedness can lead to the development of different experiences (sensory, affective, cognitive, physical and social). Experiential retail will inevitably result in the creation of an experience in the same way that every incident a person is involved in creates an experience. However, the challenge lies in creating a memorable experience which, when emerged in it, urges consumers to spontaneously react to offers to not only satisfy consumers' desires but also promise desirable outcomes for retailers. In creating such experiences, an understanding of the internal motives that drive consumers in actual experiential venues is crucial.

Investigation of consumers' behaviour in experiential retail contexts is limited. In 2007, Fiore and Kim developed a framework capturing experiential and utilitarian shopping experiences through synthesising variables deduced from previous studies without empirically testing the framework. The study also did not focus on consumers' impulsive behaviour, which is central to consumers' behaviour in experiential retail contexts. Extant literature that addresses consumers' behaviour, specifically their impulsive behaviour, is still sparse. This study addresses the shortcomings depicted in existing theories and literature by empirically identifying the internal driving forces that predict consumers' impulsive behaviour in experiential retail settings.

\section{Development of the conceptual model}

The theoretical background for the study integrates existing research on impulsive behaviour and prominent factors identified within experiential retail literature. Two prominent theoretical approaches, one representing impulsive behaviour (Muruganantham \& Bhakat 2013) and the other experiential retail (Arnold \& Reynolds 2003), were merged. This led to the 
identification of the most prominent variables that might explain consumers' impulsive behaviour in an experiential retail context. Figure 1 indicates the respective variables that were deduced for the study as well as additional literature in support of this.

Muruganantham and Bhakat (2013) studied impulse behaviour in traditional retail settings by extracting secondary information from over 50 years' publications. Nine internal factors that seem prominent to prompt consumers' impulsive behaviour were identified, namely emotions, hedonism, fashion, normative evaluation, variety seeking, enjoyment, impulsiveness, self-identity as well as product involvement.

Empirical studies on experiential retail indicate that mood and emotions, hedonism and recreation (enjoyment) are related to consumers' behaviour in an experiential retail setting. Regarding hedonism, Arnold and Reynolds (2003) further identified six different hedonic desires, namely adventure, gratification, value, idea, social and role shopping, to represent the various pleasurable motives that might drive consumers' shopping. These hedonic desires concur with the factors that were identified by Muruganantham and Bhakat (2013). Idea shopping represents fashion, while gratification shopping represents normative evaluation and adventure shopping represents variety seeking. The different hedonic desires as termed by Arnold and Reynolds (2003) are used to describe the hedonic constructs appropriate to experiential retail.

In this study, three of the constructs identified by Muruganantham and Bhakat (2013) were excluded, namely (1) impulsivity as a lifestyle trait because the nature of experiential retail, often temporary, novel and scarce, arouses impulsivity even in visitors who are not typically impulsive, (2) self-identity, arguing that impulsive behaviour in an experiential context does not transpire as an attempt to express or reflect the inner self but merely to enhance the experience or to acquire memorabilia and (3) Product involvement as an influence on consumers' impulsive behaviour in an experiential retail context, arguing that in an experiential retail setting, the environment rather than the products gets consumers immersed.

Based on the amalgamation of factors, the hypothesised relationships between the independent factors and consumers' impulsive behaviour as the dependent variable are subsequently explicated.

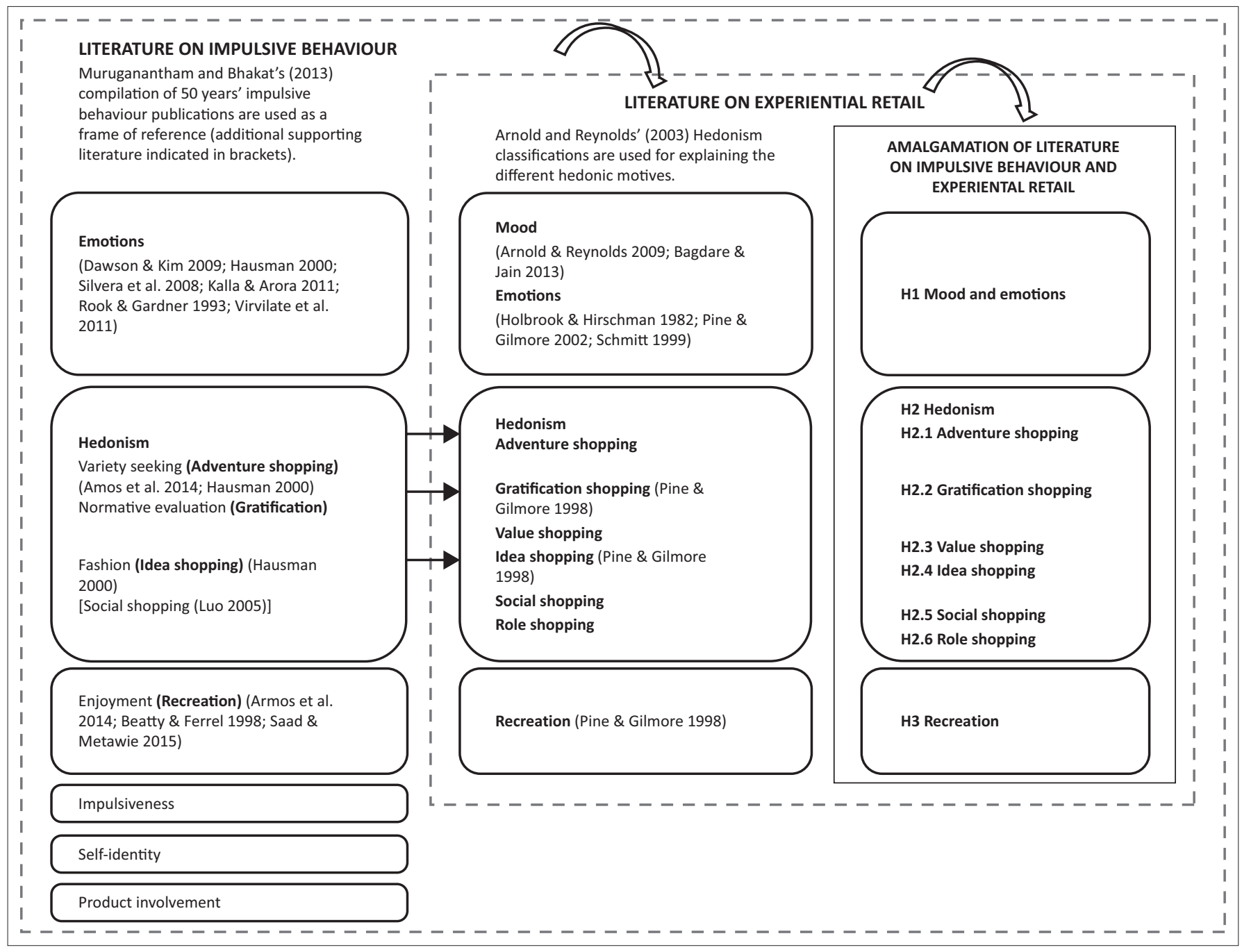

FIGURE 1: Theoretical background. 


\section{Impulsive behaviour in an experiential retail context}

In an earlier study on impulse behaviour, Beatty and Ferrel (1998) identified the need to differentiate between an urge to purchase something impulsively and impulsive purchases per se. An urge to purchase merely represents an irresistible desire creation that precedes the actual deed of purchasing (Beatty \& Ferrel 1998; Kim 2003). This irresistible desire creation can either develop during the process of browsing, through positive emotions experienced while shopping, owing to the proximity of desired merchandise or based on a personal tendency to engage in impulsive purchasing (Beatty \& Ferrel 1998). In another study, Kim (2003) also explains that the process of impulsive purchasing commences when consumers browse. Browsing creates awareness of stimuli exposure to which subsequently creates a desire within consumers that prompts them to make a purchase. Consequences are only considered during the post-purchase evaluation process (Kim 2003).

Experiential retail focuses on providing memorable experiences and aims to engage consumers in the retail experience. Unlike traditional retail stores that are primarily focused on selling products or services to consumers, it is not uncommon for experiential retailers to exclude these from their retail strategy. This implies that consumers might not necessarily be able to follow through with the impulsive behavioural process as set out by Kim (2003) as the unavailability of merchandise will impede the result of impulse purchases. Furthermore, certain experiential retailers provide activities to partake in as part of the experience. For this reason, the study also acknowledged impulse participation in activities as an outcome.

Based on these differences between experiential retail and traditional retail contexts, impulsive behavioural outcomes were separated to explore impulse participation as an additional outcome and to determine whether all irresistible cravings eventually lead to impulsive acts. This was done to obtain more accurate outcomes and useful recommendations for retailers in terms of inclusion of additional offers. Theoretically, this will also direct the development of impulsive behavioural models portraying the behaviour of consumers in experiential retail settings. These three behavioural outcomes can be conceptualised as follows: firstly, an irresistible desire is an overpowering inner feeling that spurs consumers to want to act (Beatty \& Ferrel 1998; Kim 2003). Secondly, impulse purchases refer to the spontaneous procurement of merchandise (Rook \& Fisher 1995; Saad \& Metawie 2015), given the availability thereof in an experiential venue. Similar to impulse purchases, impulse participation in activities also refers to an impulsive behavioural action. However, it refers to consumers' unplanned participation in activities offered at experiential venues.

\section{Mood and emotions}

This study regarded mood and emotions as an intertwined concept that relates to nearly all aspects of consumption behaviour which are relevant during consumers' impulsive behaviour (Arnold \& Reynolds 2009; Hausman 2000; Kalla \& Arora 2011; Ozer \& Gultekin 2015; Silvera et al. 2008; Verplanken \& Sato 2011; Youn \& Faber 2000). Emotions can turn into a mood (e.g. happiness leading to a positive mood) and a mood can influence a person emotionally (e.g. a positive mood may bring about excitement). Mood preexists when a consumer enters a retail setting (Ungerer 2014) and, whether positive or negative, potentially influences the consumer's impulsive behaviour (Arnold \& Reynolds 2012; Blythe 2013). When in a positive mood, consumers tend to reward themselves to preserve the current mood state or to experience a sense of freedom. Consequently, consumers may act on impulse (Arnold \& Reynolds 2009; Ozer \& Gultekin 2015). When in a positive mood, consumers perceive decisions as less complex and make decisions much faster (Blythe 2013). In contrast, a person in a negative mood might intentionally visit a retailer for so-called retail therapy (Arnold \& Reynolds 2012; Kalla \& Arora 2011). Not surprising then, a negative mood seems to have a stronger influence on impulsive behaviour than a positive mood (Amos et al. 2014).

Mood has further been identified by Bagdare and Jain (2013) as one of the constructs contributing to retail customer experience. Retailers can thus skilfully create elements that would improve a consumer's mood state to increase visits, encourage browsing and improve consumer spending. Previous research confirmed that retail environmental characteristics may positively affect consumers' emotions (Chang, Yan \& Eckman 2014; Kim \& Kim 2012). It has also been confirmed that a positive association exists between the emotions derived from an experiential shopping experience and an increase in unplanned purchases (Bäckström \& Johansson 2006; Chang et al. 2014; Verplanken \& Sato 2011). Accordingly, it is hypothesised that:

H1: In an experiential retail environment, mood and emotions as an intertwined construct positively predicts consumers': $\mathbf{H 1} \mathbf{a}_{\mathbf{a}}$ irresistible desire creation; $\mathbf{H} \mathbf{1}_{b}$ impulse purchases; $\mathbf{H} \mathbf{1}_{\mathbf{c}}$ impulse participation in activities.

\section{Hedonism}

Experiential retail encompasses a steady flow of fantasies, feelings and fun that are conducive to impulsive behaviour (Kalla \& Arora 2011; Verplanken \& Sato 2011). The uniqueness of the experiences, novelty elements and stimuli allow consumers to become immersed in the retail experience and to produce their own multi-sensory images that are unrelated to prior experiences (Kalla \& Arora 2011). These imaginative constructions of reality serve as hedonic motivation for consumers to impulsively engage in activities or to purchase products on the spot. Hedonic consumption is hence based on what consumers long for rather than the reality (Kalla \& Arora 2011). Six hedonic shopping motivations (Arnold \& Reynolds 2003 , 2012) may be satisfied during an experiential retail visit.

Adventure shopping represents consumers' motivation to seek excitement and adventure during a shopping trip 
(Arnold \& Reynolds 2003). Experiential venues often attract the attention of consumers to have a good time without any intent to purchase products. The temporary nature of some experiential venues such as Pop-up stores, creates a sense of excitement within consumers. This excitement often spurs spontaneous reaction to take up special offerings to treasure a memorable visit. More permanent experiential venues are also focused on continuously changing the retail environment to keep visitors interested and ensure that each experience holds the promise of a new adventure. Hedonic motivations such as fun, surprise and thrillseeking were identified to stimulate impulse purchasing (Amos et al. 2014; Hausman 2000). Accordingly, it is hypothesised that:

H2.1 In an experiential retail environment, adventure shopping positively predicts consumers': H2.1 a irresistible desire creation; H2.1 I $_{\mathrm{b}}$ pulse purchases; $\mathbf{H} 2 . \mathbf{1}_{\mathrm{c}}$ impulse participation in activities.

Gratification shopping represents the escapism realm as identified by Pine and Gilmore (1998). This implies that each consumer contributes in creating an experience as entrants are involved in terms of actual participation in live performances, movie showcasing and interactive activities. This allows visitors to adopt a new persona and ultimately forget about their sorrows (Arnold \& Reynolds 2003; Pine \& Gilmore 1998). Consumers regard such involvement appropriate arguing that they deserve the offerings in the venue as a treat to themselves. Hence, it is hypothesised that:

H2.2 In an experiential retail environment, gratification shopping positively predicts consumers': H2.2 $\mathrm{a}$ irresistible desire creation; $\mathbf{H} 2.2_{\mathrm{b}}$ impulse purchases; $\mathbf{H} 2 . \mathbf{2}_{\mathrm{c}}$ impulse participation in activities.

Value shopping entails shopping for bargains and discounted products (Arnold \& Reynolds 2003). In terms of experiential retail, it also comprises the purchase of exclusive products. Experiential venues, especially the ones with a temporary nature, propagate products or services with a 'miss it, miss out forever' approach. Some even deliberately promote a sense of 'bargain shopping' so that visitors can lay their hands on products that others would struggle to find. Because every encounter and the related experience in an experiential setting are unique to the individual (Bagdare \& Jain 2013; Pine \& Gilmore 1998), visitors generally try to purchase something to preserve the memory. Every experiential retail experience is potentially a hedonically pleasing value shopping encounter that would be difficult or impossible to reproduce, urging impulse reaction. Therefore, it can be hypothesised that:

H2.3 In an experiential retail environment, value shopping positively predicts consumers': H2.3 irresistible desire creation; $\mathbf{H} 2.3_{\mathrm{b}}$ impulse purchases; $\mathbf{H} 2.3_{\mathrm{c}}$ impulse participation in activities.

Experiential venues are focused on continuous innovation with incorporation of the latest trends and ideas. Idea shopping motives thus support the educational realm as it creates opportunity to learn more about the latest trends and ideas through exposure to innovative products, active participation in the experience and creative ideas that might be inspirational (Pine \& Gilmore 1998). Novelty as a hedonic motive has been identified to influence consumers' impulsive behaviour (Hausman 2000) which supports the hypothesis that:

H2.4 In an experiential retail environment, idea shopping positively predicts consumers': H2.4 irresistible desire creation; $\mathbf{H} 2.4_{\mathrm{b}}$ impulse purchases; $\mathbf{H} 2 . \mathbf{4}_{\mathrm{c}}$ impulse participation in activities.

Social shopping entails patronising retail establishments to spend time with friends or relatives (Arnold \& Reynolds 2003). Experiential retailing offers an opportunity for an enjoyable socialising experience at extraordinary establishments where patrons are encouraged to participate in activities on the spur of the moment, for example through participation in unique activities. Social shopping motives have been identified to enhance impulse buying, especially when hanging out with friends (Luo 2005). Accordingly, it is hypothesised that:

H2.5 In an experiential retail environment, social shopping positively predicts consumers': $\mathbf{H} 2 . \mathbf{5}_{\mathrm{a}}$ irresistible desire creation; $\mathbf{H} 2.5_{b}$ impulse purchases; $\mathbf{H} 2.5_{c}$ impulse participation in activities.

Role shopping occurs when consumers shop for or on behalf of others, or when visiting destinations to treat someone else (Arnold \& Reynolds 2003). Mostly, the products offered in experiential retail settings are unique to the context, allowing visitors to spoil someone with exceptional items or by purchasing memorabilia to retrospectively nurture a sense of nostalgia which might spur impulsive behaviour as hypothesised:

H2.6 In an experiential retail environment, role shopping positively predicts consumers': $\mathbf{H} 2 . \mathbf{6}_{\mathrm{a}}$ irresistible desire creation;

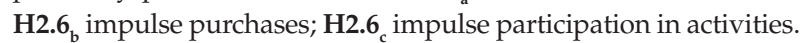

\section{Recreation}

Consumers often devote considerable time to procure products and services for recreational purposes to satisfy personal and social motives (Singh, Sinha \& Mishra 2013). Browsing in retail environments could be a favourite pastime and a form of leisure, which is referred to as recreational shopping (Bagdare \& Jain 2013; Guiry, Mägi \& Lutz 2006; Kalla \& Arora 2011). Prolonged shopping time, even after procurement, increased spending per trip and increased unplanned purchases are typical among recreational shoppers (Guiry et al. 2006; Kim \& Kim 2007; Murphy et al. 2011).

Recreational shoppers are mostly also variety seekers rather than creatures of habit and are likely to try new products and experiences (Guiry et al. 2006; Hattingh et al. 2012). For these consumers, product newness and exploring new and interesting retail settings which experiential retail formats are known for offer the stimulation and enjoyment they desire (Singh et al. 2013). This is contrary to economic shoppers, who generally try to minimise time and effort and attempt to optimise value and convenience while shopping 


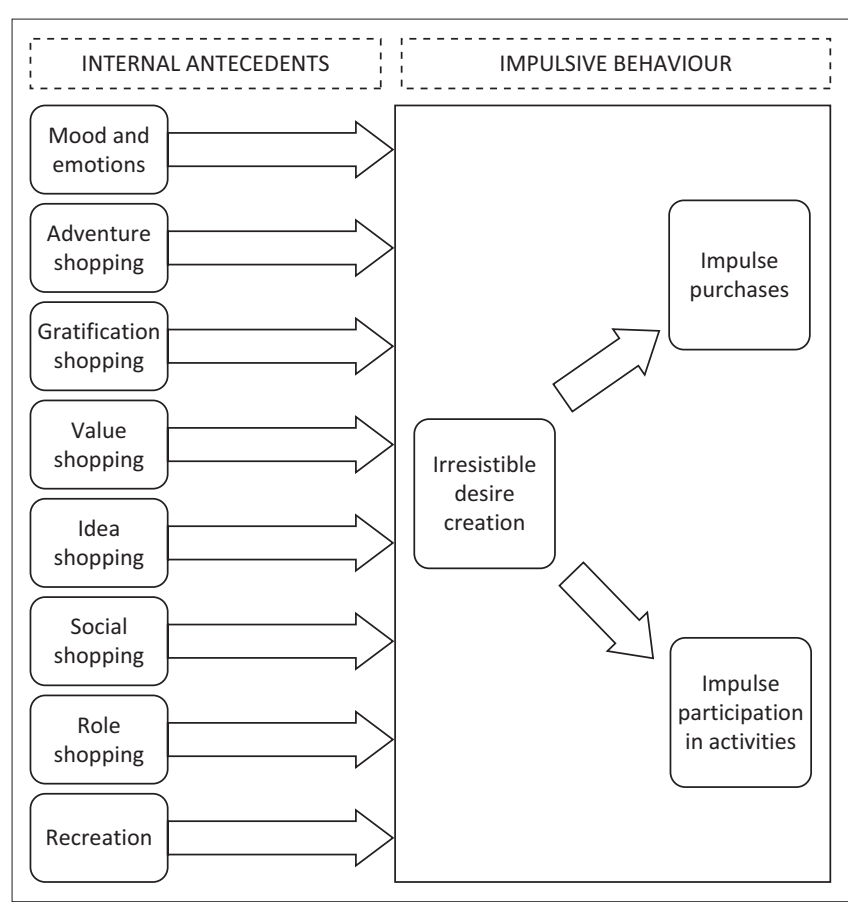

FIGURE 2: Conceptual framework.

(Fiore, Jin \& Kim 2005; Murphy et al. 2011). Accordingly, it is also hypothesised that:

H3 In an experiential retail environment, recreation positively predicts consumers': $\mathbf{H} \mathbf{3}_{\mathbf{a}}$ irresistible desire creation; $\mathbf{H} \mathbf{3}_{\mathbf{b}}$ impulse purchases; $\mathrm{H}_{\mathrm{c}}$ impulse participation in activities.

The conceptual framework (Figure 2) graphically depicts the proposed relationships between the constructs of the study.

\section{Methodology}

This cross-sectional quantitative study followed a deductohypothetico approach (Walliman 2005), which implies that the hypotheses were deduced from existing literature. The hypotheses aimed to confirm relationships among independent and dependent variables (Aaker et al. 2011; Hopkins 2000). The electronic survey was economical, enabled a rapid turnaround in data collection and permitted the recruitment of respondents from a broad geographical area based on the large database of an established research company, Consulta Pty Ltd. (Creswell 2014).

A pre-test aimed at a minimum of 100 responses was launched on 10 July, 2015. A total of 225 responses were obtained during 3 days. The internal consistency of items measuring the same construct was assessed by means of Cronbach's alpha to detect problematic items (items that did not correlate sufficiently with others measuring the particular construct). Problematic items were reworded to improve reliability, face validity and clarity. The pre-test further included 11, instead of the 8 retailers respondents could refer to. However, results indicated that because some of the 11 retailers only incorporate certain elements of the experiential approach in their service delivery such as having a theme and thematic products on offer while predominantly operating a traditional retail format, respondents got confused. All retailers included were therefore reselected during a focus group session by an expert panel and limited to only eight, which could be classified as fully experiential. This necessitated the need for a pilot test, also aimed at 100 responses, which was launched on 25 August, 2015. The study was closed on retrieval of 101 responses. After consultation with a statistician, the questionnaire was deemed reliable and valid and the final questionnaire was fielded.

The final data collection that took place from 18 September to 5 October, 2015, delivered a total of 402 usable questionnaires. Worth mentioning is that 1460 interested candidates did not meet the requirements to participate as they did not visit one of the eight identified experiential retailers. Even though the participation rate decreased dramatically after limiting the retailers to fully experiential ones, the inclusion of fully experiential retailers enabled more accurate measurement within an experiential retail context and improved the validity of data. In order to calculate the minimum sample size for the bigger study, the recommendations of Tabachnick and Fidell (2013) were followed, namely, $N>50+8 \mathrm{~m}$ (m indicates the number of independent variables). Considering that this formed part of a broader study including six independent variables, 98 questionnaires were required. However, for stepwise multiple regression analysis, it is recommended that a ratio of 40 cases is required for every independent variable (Pallant 2013), which amounts to 240 questionnaires. This target was easily exceeded.

A heterogeneous sample of South African citizens that included males and females, 18 years of age or older, from various ethnic backgrounds, with divergent educational levels and annual earnings, was recruited electronically. Non-probability, purposive sampling was employed to recruit willing respondents, who have previously visited one of the identified experiential retailers. The investigation required consumers' retrospective evaluation of their actual experience at one of the selected eight experiential retailers. These retailers represent different types of experiential retail formats such as themed restaurants, experiential retail stores, experiential destinations and Pop-up stores. Table 1 provides a concise description of each of these experiential retailers.

These stores are further representative of fully experiential retailers. This implies that the retailer incorporates an experiential approach in every aspect related to the business and not only in the designing of the store or products. A prerequisite for respondents to participate in the study was having visited at least one of the listed establishments within the 3-year period preceding the data collection. Three years were considered appropriate bearing in mind that at the time of data collection, only a limited number of fully experiential retailers were operating in South Africa and that some experiential retailers have a temporary nature such as Pretville, Pestaurant and the Magnum Pop-up store. Consumers more easily recall positive experiences than negative ones (Kim, Ritchie \& McCormick 2012) and tend to 
TABLE 1: Description of the selected experiential retailers.

\begin{tabular}{|c|c|}
\hline Experiential retailer (Location) & Description of the retailer \\
\hline Hard Rock Café (Gauteng) & $\begin{array}{l}\text { An internationally well-known restaurant designed around a Rock ' } n \text { Roll theme. The café has a stage where bands can } \\
\text { perform, while consumers enjoy signature hamburgers in a venue decorated with Rock ' } n \text { Roll memorabilia from famous } \\
\text { Rock stars. Adjacent to the store is its Rock Shop, selling among other items, branded t-shirts indicating the country or city } \\
\text { the t-shirt was sold in. These t-shirts have become popular collectors' items. }\end{array}$ \\
\hline Pestaurant (Gauteng, Western Cape) & $\begin{array}{l}\text { This temporary Pop-up restaurant is a global initiative joined by } 12 \text { countries partaking in the retailing initiative on the same } \\
\text { day. The restaurant offers a variety of sweet or savoury insect snacks. Pestaurant was hosted in South Africa by a pest control } \\
\text { company, Rentokil, who used the initiative to make their slogan 'bites back at bugs' come to life. }\end{array}$ \\
\hline Die BlouHond (Gauteng) & $\begin{array}{l}\text { This is a thematic restaurant where performances by South African musicians are offered in conjunction with a three-course } \\
\text { meal. The theme revolves around the mascot, a blue dog. Patrons are welcomed as dogs and bitches and are encouraged to } \\
\text { bark instead of applauding. }\end{array}$ \\
\hline Greensleeves (Gauteng) & $\begin{array}{l}\text { Greensleeves Medieval Kingdom is an entertainment restaurant where patrons dress up in medieval outfits that can be hired } \\
\text { at the venue. Patrons are addressed as Milord and Milady and are entertained by the Baron and his Minstrels. }\end{array}$ \\
\hline $\begin{array}{l}\text { Cape Union Mart Adventure Centre (KwaZulu-Natal, } \\
\text { Western Cape) }\end{array}$ & $\begin{array}{l}\text { Cape Union Mart, a South African retailer in outdoor equipment and gear, opened experiential adventure centres where } \\
\text { visitors can experience an outdoor experience indoors. These stores have distinctive features such as a rain chamber, a cold } \\
\text { weather chamber as well as a climbing wall that can specifically be used to test clothes and accessories. }\end{array}$ \\
\hline Pretville (North West) & $\begin{array}{l}\text { This small fictional town from the late 1950s was created in } 2013 \text { to serve as a film set for the movie Pretville. The movie } \\
\text { scene was preserved to generate additional funds, while the movie showed at cinemas. The town soon attracted thousands } \\
\text { of curious people who could watch the movie in Pretville's 1950-style bioscope and dress up in fashion of the time. }\end{array}$ \\
\hline Magnum Pop-up store (Gauteng, Western Cape) & $\begin{array}{l}\text { Magnum globally launched Magnum Pleasure Pop-up stores offering a 'Make My Magnum Experience' to consumers around } \\
\text { the world in celebration of their } 25 \text { th birthday. Participants were guided through a six-step process that concluded with } \\
\text { requests to share their experiences on social media. }\end{array}$ \\
\hline
\end{tabular}

remember their best experiences, as opposed to materialistic purchases where consumers tend to best recall the worst ones (Martin, Reimann \& Norton 2015). Respondents who had visited more than one experiential retail setting before completed the survey based on their most memorable experience to ensure the recall of specific behavioural reactions encountered while there. Limiting the point of reference to a single experiential retail trip enabled effective comprehension of impulsive behaviour within a specific experiential retail environment. The electronic survey enabled automatically substituting the selected retailer's name in relevant questions to constantly remind respondents to refer to the same experience.

A total of 17 questions and 43 items included in the electronic questionnaire are relevant to report on in this study. Two questions in the questionnaire identified the experiential retailers that were patronised as the most memorable visit. Two screening items were used to restrict access to items pertaining to purchases and activities to only respondents who had actually purchased items or taken part in experiences in the respective experiential retail settings during their visit (Table 2). Seven questions related to the dependent and independent variables; five questions gathered demographic information using nominal scales. Income and education level were measured in alignment with the predetermined classification criteria.

An 11-point Likert-type agreement scale was considered most suitable to measure the constructs of the study (mood and emotions, adventure, gratification, value, idea, social and role shopping, recreation, irresistible desire creation, impulse purchases and impulse participation), where $0=$ strongly disagree and $10=$ strongly agree. Considering that this formed part of a bigger study which required the use of more advanced statistical analyses, including Covariance-Based Structural Equation Modeling (CB-SEM), 11 points were considered more suitable for the analyses requirements as well as to enhance construct validity
(Awang, Afthanorhan \& Mamat 2016). The 25 items measuring the independent variables originated from previous research (Arnold \& Reynolds 2003; Kim 2003; Mathwick, Malhotra \& Rigdon 2001) but were adapted to allow retrospective assessment of the visit at a specific experiential retailer instead of relating to shopping behaviour in general. The scales from which items were adapted were proven reliable and valid in the studies from which they originate (Arnold \& Reynolds 2003; Kim 2003; Mathwick et al. 2001). Irresistible desire creation was investigated by means of three items that were self-formulated based on the literature. The three items related to impulse purchases and four items related to impulse participation were adapted from Rook and Fisher (1995) (Table 2).

One item pertaining to impulse purchases as well as one pertaining to impulse participation was removed as they were reverse coded items, causing consistency concerns. The Cronbach's alphas subsequently increased from 0.57 to 0.62 for impulse purchases and from 0.63 to 0.70 for impulse participation. Considering Hinton et al.'s (2004) guidelines for assessing reliability results, wherein Cronbach's alpha values between 0.50 and 0.69 are regarded as moderately reliable and values of 0.70 and above as highly reliable, internal consistency reliability is confirmed.

\section{Demographic information}

Table 3 indicates that the male and female distribution was almost equal with most respondents aged between 26 and 55 years. White people and Africans dominated the ethnic representation. Respondents were well educated, while lower to middle income categories were strongly represented.

\section{Data analysis}

The statistics program IBM@SPSSC23 was used to analyse the data. Internal consistency reliability was assessed by evaluating Cronbach's alpha values (De Vellis 2012). Stepwise 
TABLE 2: Items and reliability measures.

\begin{tabular}{|c|c|c|}
\hline Factors & Items & Cronbach's $\alpha$ \\
\hline Mood and emotions & $\begin{array}{l}\text { The experience at the venue: } \\
\text { lifted my mood. } \\
\text { was exciting. } \\
\text { made me feel happy and cheerful. }\end{array}$ & 0.96 \\
\hline $\begin{array}{l}\text { Hedonism } \\
\text { Adventure shopping }\end{array}$ & $\begin{array}{l}\text { The experience at the venue: } \\
\text { was adventurous. } \\
\text { was stimulating } \\
\text { made me feel as if I was exploring new worlds. } \\
\text { The venue offered a quick opportunity for fun. }\end{array}$ & 0.91 \\
\hline Gratification shopping & $\begin{array}{l}\text { The experience at the venue: } \\
\text { was an escape from reality. } \\
\text { was an opportunity to spoil myself. } \\
\text { was stress relieving. }\end{array}$ & 0.83 \\
\hline Value shopping & $\begin{array}{l}\text { The experience at the venue: } \\
\text { was priceless because I know I might not be able to experience it again. } \\
\text { was much better than any experience I had at another restaurant/retailer/cinema. } \\
\text { The visit to the venue: } \\
\text { enabled me to experience something exclusive. }\end{array}$ & 0.83 \\
\hline Idea shopping & $\begin{array}{l}\text { The visit to the venue: } \\
\text { kept me updated with the latest trends and ideas. } \\
\text { was more interesting than that to traditional restaurants/retailers/cinemas. } \\
\text { satisfied my sense of curiosity. }\end{array}$ & 0.86 \\
\hline Social shopping & $\begin{array}{l}\text { The visit to the venue: } \\
\text { was great for socialising. } \\
\text { was great to meet up with friends or family. } \\
\text { allowed me to bond with others. }\end{array}$ & 0.91 \\
\hline Role shopping & $\begin{array}{l}\text { The visit to the venue: } \\
\text { enabled me to purchase something unique for someone special. } \\
\text { was a good opportunity for me to treat someone special. } \\
\text { was the perfect gift for someone special. }\end{array}$ & 0.90 \\
\hline Irresistible desire creation & $\begin{array}{l}\text { The temptation for a good experience was difficult to resist. } \\
\text { The offerings looked too promising to pass up. } \\
\text { The whole setup at the venue created a desire within me. }\end{array}$ & 0.91 \\
\hline Impulse purchases & $\begin{array}{l}\text { I didn't plan on purchasing anything but decided to do so while I was at the venue. } \\
\text { I spontaneously bought something. }\end{array}$ & 0.62 \\
\hline Removed & I decided what I was going to buy before I visited the venue. (Reverse coded) $\dagger$ & \\
\hline Impulse participation in activities & $\begin{array}{l}\text { I planned some of the activities that I engaged in but decided to partake in the rest on the spur of the moment. } \\
\text { I spontaneously decided to partake in an activity at the venue. } \\
\text { I didn't know about all the activities offered at the venue but decided to partake on the spot. }\end{array}$ & 0.70 \\
\hline Removed & I knew exactly what I wanted to do at the venue and ended up only doing what I planned. (Reverse coded) $\dagger$ & \\
\hline
\end{tabular}

$\dagger$, Items that were removed as they jeopardised the internal consistency.

multiple regression analysis was subsequently conducted to test the hypothesised relationships between the independent and dependent variables. The cut-off value for significance is $p \leq 0.05$ (Malhotra 2010). The purpose of regression analysis is to determine whether the independent variables explain a significant variation in the dependent variable and confirm the existence of a relationship (Malhotra 2010). This study specifically aimed at exploring the best predictor variables.

\section{Ethical considerations}

Ethical clearance was obtained from the University of Pretoria prior to data collection (reference number: EC150410007). Participation was voluntary and an information letter preceding the survey explained the purpose of the survey. Anonymity of identity and confidentiality of information provided by respondents are assured by Consulta and the researchers. Responses were not changed in any way to attain desirable outcome. The work of other authors was acknowledged to guard against plagiarism.

\section{Results and interpretation}

Cronbach's alpha values were calculated for each of the constructs to ensure adequate internal consistency (see Table 2). All independent variables portrayed high Cronbach's alpha values (mood and emotions $=0.96$; adventure shopping $=0.91$; gratification shopping $=0.83$; value shopping $=0.83$; idea shopping $=0.86$; social shopping $=0.91$; 
role shopping $=0.90$; recreation $=0.88$ ). The same was true for irresistible desire creation, with a Cronbach's alpha value of 0.91. Impulse purchases portrayed moderate internal consistency reliability with a Cronbach's alpha value of 0.62 , while impulse participation portrayed high internal consistency reliability with a Cronbach's alpha value of 0.70 (Hinton et al. 2004).

Stepwise multiple regression analysis was conducted to explain the variability by means of the significant independent variables. Based on the assumptions of multiple regression analysis (Hair et al. 2014), the following confirm regression analyses as appropriate to analyse the data. Pearson's correlation coefficient identified adequate linear association between variables, exceeding 0.3 in most instances (Pallant 2013). The linearity of residuals was confirmed by means of a scatter plot. The data were retrieved cross-sectionally to

TABLE 3: Demographic profile of sample $(n=402)$.

\begin{tabular}{|c|c|c|}
\hline Demographics & Sample size $(n)$ & Percentage (\%) \\
\hline \multicolumn{3}{|l|}{ Gender } \\
\hline Male & 207 & 51.5 \\
\hline Female & 195 & 48.5 \\
\hline \multicolumn{3}{|l|}{ Age } \\
\hline $18-25$ years & 21 & 5.2 \\
\hline $26-35$ years & 94 & 23.4 \\
\hline $36-45$ years & 91 & 22.6 \\
\hline $46-55$ years & 106 & 264 \\
\hline $56-65$ years & 67 & 16.7 \\
\hline$>65$ years & 23 & 5.7 \\
\hline \multicolumn{3}{|l|}{ Ethnicity } \\
\hline White people & 248 & 61.7 \\
\hline Africans & 84 & 20.9 \\
\hline Asians & 34 & 8.5 \\
\hline Mixed race & 21 & 5.2 \\
\hline Undeclared & 15 & 3.7 \\
\hline \multicolumn{3}{|l|}{ Education level } \\
\hline Did not complete secondary school & 7 & 1.8 \\
\hline Secondary school & 70 & 17.4 \\
\hline Undergraduate & 32 & 8.0 \\
\hline Degree/diploma & 175 & 43.5 \\
\hline Postgraduate & 113 & 28.1 \\
\hline Missing values & 5 & 1.2 \\
\hline \multicolumn{3}{|l|}{ Personal monthly income } \\
\hline $\begin{array}{l}\text { Lower income to emerging middle class } \\
(<\mathrm{R} 25000)\end{array}$ & 184 & 45.8 \\
\hline $\begin{array}{l}\text { Realised to upper middle class (R25 } 001 \text { - } \\
\text { R60 000) }\end{array}$ & 117 & 29.1 \\
\hline Emerging affluent to affluent (> R60 000) & 54 & 13.4 \\
\hline Undeclared & 47 & 11.7 \\
\hline
\end{tabular}

eliminate independency concerns. Homoscedasticity of plotted residuals and normality assumption based on histogram outcome were visually assessed as reasonable.

Stepwise regression analysis results identified mood and emotions $(B=0.309 ; p<0.0005)$ as the best significant positive predictor of irresistible desire creation, followed by recreation $(B=0.307 ; p<0.0005)$ and gratification shopping $(B=0.232$; $p<0.0005)$. The explanatory value $R^{2}$ indicates that these three variables cumulatively account for $61 \%$ of the variance explained in irresistible desire creation.

Table 4 indicates that four variables emerged as significant predictors for impulse purchases. The relationship between mood and emotions $(B=-0.302 ; p=0.001)$ and impulse purchases is significantly negative. Gratification shopping ( $B=0.297 ; p=0.002)$ was identified as the best positive predictor of impulse purchases, followed by adventure shopping $(B=0.287 ; p=0.018)$ and social shopping $(B=0.171$; $p=0.022$ ). Based on a cumulative explanatory value of $23 \%$, impulse purchases are not strongly predicted by the variables that were attended to in this study.

In order of best predictors, results show that gratification shopping $(B=0.341 ; p<0.0005)$, adventure shopping $(B=$ $0.194 ; p=0.042)$ and social shopping $(B=0.186 ; p=0.007)$ are significant positive predictors of impulse participation in activities. These three factors altogether account for $42 \%$ of the variance explained in impulse participation.

The significant positive relationship between mood and emotions and irresistible desire creation supports $\mathrm{H} 1_{\mathrm{a}}$. This suggests that the experience at an experiential venue is satisfactory as it leaves consumers with a craving for more. Support was also confirmed for $\mathrm{H}_{1}$ in that a significant negative relationship exists between mood and emotions and impulse purchases. The relationship between mood and emotions and impulse participation is insignificant, thereby not supporting $\mathrm{H}_{1}$. These findings imply that the yearning for more will not necessarily culminate in purchases or participation in activities. This supports previous research that a negative mood state might be more conducive to impulse purchases than a positive mood state (Baumeister 2002; Verplanken et al. 2005). Hence, visitors who are already content might refrain from purchasing products or participating in activities to preserve their mood or because they do not need something to support their positive mood state.

TABLE 4: Results for regression analyses.

\begin{tabular}{|c|c|c|c|c|c|c|}
\hline \multirow[t]{2}{*}{ Independent variables } & \multicolumn{2}{|c|}{ Irresistible desire creation } & \multicolumn{2}{|c|}{ Impulse purchases } & \multicolumn{2}{|c|}{ Impulse participation } \\
\hline & $B$ & $p$ & $B$ & $p$ & $B$ & $p$ \\
\hline Mood and emotions & 0.309 & 0.000 & -0.302 & 0.001 & -0.090 & 0.348 \\
\hline Adventure shopping & 0.063 & 0.423 & 0.287 & 0.018 & 0.194 & 0.042 \\
\hline Gratification shopping & 0.232 & 0.000 & 0.297 & 0.002 & 0.341 & 0.000 \\
\hline Value shopping & 0.008 & 0.891 & -0.136 & 0.178 & -0.049 & 0.597 \\
\hline Idea shopping & 0.066 & 0.281 & -0.023 & 0.820 & -0.069 & 0.415 \\
\hline Social shopping & 0.022 & 0.628 & 0.171 & 0.022 & 0.186 & 0.007 \\
\hline Role shopping & 0.033 & 0.365 & 0.051 & 0.380 & -0.063 & 0.242 \\
\hline Recreation & 0.307 & 0.000 & 0.104 & 0.344 & -0.037 & 0.716 \\
\hline
\end{tabular}

$B$, regression. 
Furthermore, any purchase or participation in activities might spoil their experience as that entails some form of risk.

With reference to $\mathrm{H} 2$, only adventure shopping, gratification shopping and social shopping seem to positively predict impulsive behaviour. The adventurous nature of experiential retail was identified as a positive predictor for impulse purchases and impulse participation, supporting $\mathrm{H} 2.1_{\mathrm{b}}$ and $\mathrm{H} 2.1$ but does not significantly predict consumers' irresistible desire creation. H2.1 a was thus not supported.

Results further support $\mathrm{H} 2.2_{\mathrm{a}^{\prime}} \mathrm{H} 2.2_{\mathrm{b}}$ and $\mathrm{H} 2.2_{\mathrm{c}}$. This confirms that the ability of experiential retail to relieve visitors' stress and to serve as distraction from everyday obligations will fuel visitors' urge to extend the experience and might even prompt them to purchase products or participate in activities on the spur of the moment.

The respective relationships between value shopping and idea shopping as well as impulse behaviour were not statistically significant $(p>0.05)$. Results did thus not support $\mathrm{H} 2.3$ and H2.4. Consumers visiting experiential retailers might therefore not do so with the aim of collecting novel ideas or purchasing exclusive, limited edition products but merely to enjoy the experience.

Social shopping positively predicts impulse purchases as well as impulse participation, supporting $\mathrm{H} 2.5_{\mathrm{b}}$ and $\mathrm{H} 2.5_{\text {c }}$ The relationship between social shopping and irresistible desire creation was not significant $(p>0.05)$, thereby not supporting $\mathrm{H} 2.5$. This is possibly owing to the perception of social risk. When visiting experiential retail venues with friends or family, consumers might feel obliged to purchase products similar to what some of their companions are doing, not to feel left out. When in a social milieu, consumers are usually more prone to conform to the behaviour of others and therefore participation in activities is more likely to occur when with significant others. Usually, friends do not want to dissociate themselves while the rest of the crowd are having fun (Hausman 2000). Irresistible desire is a personal state and unless it progresses into action, nobody else is exposed to, or experiences it. Therefore, others do not socially benefit from an individual's behavioural state. Neither can they be disappointed by not experiencing it in a crowd, as it is solely internal and does not reflect externally at all. The absence of a significant relationship with irresistible desire despite the depicted significant relationship with impulse purchases and impulse participation indicates that an irresistible desire does not necessarily precede a consumer's impulsive behavioural actions (purchases or participation). This is a valuable theoretical contribution to acknowledge different impulsive behavioural outcomes in the context of experiential retail.

Results did not support $\mathrm{H} 2.6$ as the relationship between role shopping and impulsive behaviour was not statistically significant $(p>0.05)$. Purchasing gifts usually involves some pre-planning, especially financial budgeting, and therefore consumers might have more control over their actions when purchasing gifts as they will not directly benefit from the product themselves. Impulsive behaviour is thus not relevant during role shopping.

The results further support $\mathrm{H}_{\mathrm{a}}$ in that recreational shopping significantly positively predicts the creation of irresistible desires. However, $\mathrm{H}_{3}$ and $\mathrm{H}_{3}$ are not supported and therefore recreation does not predict impulse purchases or impulse participation. This implies that consumers who enjoy shopping as a pastime do not necessarily have the intention to purchase products or participate in activities. Visitors to experiential retailers might subsequently merely visit the venue for enjoyment and to spend leisure time (Fiore et al. 2005). Shopping is nowadays regarded as a recreational activity and experiential retail has all the elements to fulfil this need. Pine and Gilmore (2011) propose that consumers pay an admission fee to visit experiential venues. This would provide retailers some financial support for their efforts to continually augment their offerings to provide recreational shoppers with a memorable experience and to remain sustainable.

\section{Conclusion and implications}

The study extended former studies that propose that mood and emotions influence consumers' impulsive behaviour (Amos et al. 2014; Bäckström \& Johansson 2006; Verplanken \& Sato 2011). However, unlike Bäckström and Johansson (2006) as well as Verplanken and Sato's (2011) conclusion of a positive association between mood and emotions and impulse purchases, this study revealed that consumers in a positive mood state are not necessarily inclined to make spontaneous purchase decisions. Results indicated that it is highly likely that consumers, who are in a positive mood, would become emotionally excited and subsequently uplifted when visiting an experiential retailer, although they would not necessarily purchase anything on impulse. Rather, they would develop an irresistible craving for more, which often culminates as the total outcome of the experience. Consumers, who do not experience experiential retail as emotionally uplifting, might towards the end of their visit impulsively decide to purchase something or take part in an activity to change their mood state. This could be attended to in future studies.

Secondly, the study expands prior research that identified hedonism as a trigger for impulsive behaviour (Amos et al. 2014; Hausman 2000; Kalla \& Arora 2011; Verplanken \& Sato 2011). The results showed that three of the six hedonic motivations could prompt impulsive behaviour in an experiential retail setting, namely adventure, gratification and social shopping. Therefore, visitors to experiential retailers who purely go for the excitement and adventure often end up indulging in impulse offerings. For them, it is imperative that experiential retailers offer experiential products and activities as they are likely to participate and take advantage of it on the spur of the moment.

The study confirmed that experiential retail environments might be attractive for consumers who are looking for instant pleasure and distraction from their everyday obligations. 
These consumers might also be viable targets to purchase products on impulse and participate in activities as a form of distraction from their busy, stressful schedules. The results revealed that social shopping often leads to impulse purchases and impulse participation in an experiential retail setting, possibly because individuals do not want to feel excluded in a group. This validates results of Dhaundiyal and Coughlan (2016) that socialising increases impulse tendencies. Experiential retailers should therefore cater for groups, offering products that can be shared, as well as group activities, along with opportunity for individual participation.

The findings could not confirm value, idea and role shopping as antecedents for impulsive behaviour in an experiential retail setting. The purpose of visiting an experiential retailer might not be to purchase exclusive products or to gather innovative ideas, but rather to merely enjoy whatever the experience entails, as is typical of adventure shopping. It is recommended that experiential retailers offer special visitation packages that cover an entrance fee, and possibly a small souvenir in addition to the basic product or service offering. This will allow role shoppers to plan the visit and take advantage of offerings at the venue without feeling pressurised to commit to additional expenses that prompt regret owing to overspending. Similar to previous research, this study also indicated that a visit to experiential retailers as a recreational outing might be enjoyable in itself even without culminating in unplanned purchases or participation in activities (Fiore \& Kim 2007). Mostly, these visitors merely attend to enjoy the experience without any purchase intentions.

This study makes a theoretical contribution through confirmation that brick-and-mortar stores can be modified to serve as recreational destinations through intentional manipulation of consumers' mood and emotions, and through optimisation of consumers' adventure shopping motives, desire for gratification and social shopping goals. It further suggests that impulsive behaviour within an experiential retail setting can transpire as one of three possible end states, namely an irresistible desire creation, impulse purchases and impulse participation in activities. An irresistible desire can be viewed as a satisfying inner feeling and a yearning for more. Unlike Beatty and Ferrel (1998) and Kim (2003), who identified an irresistible desire as a preceding mediator for further impulse actions, this study revealed it as an end state, which is not an additional behavioural action that might lead to increased sales or immersive participation. Such an experience nevertheless creates a foundation for good public relations, positive word-of-mouth and helps to attain a sustainable competitive advantage and customer loyalty, which are highly sought-after outcomes for prosperity in today's competitive retail environments.

\section{Acknowledgements}

The authors extend their gratitude to Prof. Francois Steffens for assistance with statistical analyses. This research is supported in part by the National Research Foundation (NRF) of South Africa and Tshwane University of Technology per the grant, Unique Grant No. 94039. Any opinion, finding and conclusion or recommendation expressed in this material is that of the authors and the NRF does not accept any liability in this regard.

\section{Competing interests}

The authors declare that they have no financial or personal relationships that may have inappropriately influenced them in writing this paper.

\section{Authors' contributions}

M-M.R. wrote the article as part of her $\mathrm{PhD}$ in Consumer Science. A.C.E. served as supervisor and D.J.P. as cosupervisor. Both A.C.E. and D.J.P. contributed valuable ideas.

\section{References}

Aaker, D.A., Kumar, V., Day, G.S. \& Leone, R.P., 2011, Marketing research: International student version, 10th edn., Wiley, Hoboken, NJ.

Amos, C., Holmes, G.R. \& Keneson, W.C., 2014, 'A meta-analysis of consumer impulse buying', Journal of Retailing and Consumer Services 21, 86-97. https://doi. org/10.1016/j.jretconser.2013.11.004

Arnold, M.J. \& Reynolds, K.E., 2003, 'Hedonic shopping motivations', Journal of Retailing 79, 77-95. https://doi.org/10.1016/S0022-4359(03)00007-1

Arnold, M.J. \& Reynolds, K.E., 2009, 'Affect and retail shopping behaviour: Understanding the role of mood regulation and regulatory focus', Journal of Retailing 85, 308-320. https://doi.org/10.1016/j.jretai.2009.05.004

Arnold, M.J. \& Reynolds, K.E., 2012, 'Approach and avoidance motivation: Investigating Hedonic consumption in a retail setting', Journal of Retailing 88(3), 399-411. https://doi.org/10.1016/j.jretai.2011.12.004

Awang, Z., Afthanorhan, A. \& Mamat, M., 2016, 'The Likert scale analysis using parametric based Structural Equation Modeling (SEM)', Computational Methods in Social Sciences 4, 13-21.

Babin, J.B. \& Harris, E., 2016, CB7, 7th edn., South-Western College Pub, [n.p].

Bäckström, K. \& Johansson, U., 2006, 'Creating and consuming experiences in retail store environments: Comparing retailer and consumer perspectives', Journal of Retailing and Consumer Services 13, 417-430. https://doi.org/10.1016/j. jretconser.2006.02.005

Bagdare, S. \& Jain, R., 2013, 'Measuring customer experience', International Journal of Retail \& Distribution Management 41(10), 790-804. https://doi.org/10.1108/ IJRDM-08-2012-0084

Baumeister, R.F., 2002, 'Reflections and reviews: Yielding to temptation: Self-control failure, impulsive purchasing and consumer behaviour', Journal of Consumer Research 28(4), 670-676. https://doi.org/10.1086/338209

Bayley, G. \& Nancarrow, C., 1998, 'Impulse purchasing: A qualitative exploration of the phenomenon', Qualitative Market Research: An International Journal 1(2), 99-114. https://doi.org/10.1108/13522759810214271

Beatty, S.E. \& Ferrell, M.E., 1998, 'Impulse buying: Modelling its precursors', Journal of Retailing 74(2), 169-191. https://doi.org/10.1016/S0022-4359(99)80092-X

Blythe, J., 2013, Consumer behaviour, 3rd edn., Sage, London.

Chang, E., 2016, Consumers are seeking irresistible experiences at shopping malls viewed 24 September 2016, from https://www.thestreet.com/story/13516816/3/ consumers-are-seeking-irresistible-experiences-at-shopping-malls.html.

Chang, H.J., Yan, R. \& Eckman, M., 2014, 'Moderating effects of situational characteristics on impulse buying', International Journal of Retail \& Distribution Management 42(4), 298-314. https://doi.org/10.1108/IJRDM-04-2013-0074

Creswell, J.W., 2014, Research design: Qualitative, quantitative and mixed methods approaches, 4th edn., Sage, London.

Dawson, S. \& Kim, M., 2009, 'External and internal trigger cues of impulse buying online', Direct Marketing: An International Journal 3(1), 20-34. https://doi. org/10.1108/17505930910945714

De Vellis, R.F., 2012, Scale development: Theory and applications, 3rd edn., Sage, Thousand Oaks, CA.

Dhaundiyal, M. \& Coughlan, J., 2016, 'Investigating the effects of shyness and sociability on customer impulse buying tendencies', International Journal of Retail \& Distribution Management 44(9), 923-939. https://doi.org/10.1108/JJRDM-12-2014-0166

Erasmus, A.C., Donoghue, D. \& Dobbelstein, T., 2014, 'Consumers' perception of the complexity of selected household purchase decisions', Journal of Retailing and Consumer Services 21, 293-305. https://doi.org/10.1016/j.jretconser.2014. 02.008 
Fiore, A.M, Jin, H.J. \& Kim, J., 2005, 'For fun and profit: Hedonic value from image interaction and responses toward an online store', Journal of Psychology and Marketing 22(8), 669-694. https://doi.org/10.1002/mar.20079

Fiore, A.M. \& Kim, J., 2007, 'An integrative framework capturing experiential and utilitarian shopping experience', International Journal of Retail and Distribution Management 35(6), 421-442.

Gentile, C., Spiller, N. \& Noci, G., 2007, 'How to sustain the customer experience: An overview of experience components that co-create value with the customer' European Management Journal 25(5), 395-410. https://doi.org/10.1016/ j.emj.2007.08.005

Guiry, M, Mägi, A.W. \& Lutz, R.J., 2006, 'Defining and measuring recreational shoppe identity', Journal of the Academy of Marketing Science 34(1), 74-83. https://doi. org/10.1177/0092070305282042

Hair, J.F., Black, W.C., Babin, B.J. \& Anderson, R.E., 2014, Multivariate data analysis, 7th edn., Pearson, Harlow.

Hattingh, D., Russo, B., Sun-Basorun, A. \& Van Wamelen, A., 2012, The rise of the African consumer: A report from McKinsey's Africa Consumer Insight Center,
viewed 20 March 2014, from http://www.mckinsey.com/global_locations/africa/viewed 20 March 2014, from http://www.mckinsey.
south_africa/en/rise_of_the_african_consumer.

Hausman, A., 2000, 'A multi-method investigation of consumer motivations in impulse behaviour', Journal of Consumer Marketing 17(5), 403-419. https://doi.org/ behaviour', Journal of Consume

Hinton, P.R., Brownlow, C., McMurray, I. \& Cozens, B., 2004, SPSS: Explained, Routledge, New York.

Holbrook, M.B. \& Hirschmann, E.C., 1982, 'The experiential aspects of consumption: Consumer fantasies, feelings and fun', Journal of Consumer Research 9(2), 132-140. https://doi.org/10.1086/208906

Hopkins, W.G., 2000, Quantitative research design, viewed 18 July 2013, from http:// www.sportsci.org/jour/0001/wghdesign.html

Jackson, T., 2005, Motivating sustainable consumption: A review of evidence on consumer behaviour and behavioural change, Sustainable Development Research Network, Surrey.

Kalla, S.M. \& Arora, A.P., 2011, 'Impulse buying: A literature review', Global Business Review 1, 145-157. https://doi.org/10.1177/097215091001200109

Kim, J., 2003, 'College students' apparel impulse buying behaviours in relation to visual merchandising', Master's dissertation, University of Georgia, Athens, GA.

Kim, H. \& Kim, Y., 2007, 'Shopping enjoyment and store shopping modes: The moderating influence of chronic time pressure', Journal of Retailing and Consumer Services 15, 410-419. https://doi.org/10.1016/j.jretconser.2007.10.003

Kim, J.E. \& Kim, J., 2012, 'Human factors in retail environments: A review', International Journal of Retail \& Distribution Management 40(11), 818-841. https://doi. org/10.1108/09590551211267593

Kim, J., Ritchie, J.R.B., \& McCormick, B., 2012, 'Development of a scale to measure memorable tourism experiences', Journal of Travel Research 51(1), 12-15. https:// doi.org/10.1177/0047287510385467

Luo, X., 2005, 'How does shopping with others influence impulse purchasing', Journa of Consumer Psychology 15(4), 288-294. https://doi.org/10.1207/s15327663 jcp1504_3

Malhotra, N.K., 2010, Marketing research: An applied orientation, 6th edn., Pearson, Upper Saddle River, NJ.

Marsland, L., 2015, The retail experience trend, viewed 05 June 2015, from http:// www.bizcommunity.com/Article/196/87/128369

Martin, J.M., Reimann, M. \& Norton, M.I., 2015, 'Risk preferences for experiences, or how desserts are like losses', Advances in Consumer Research 43, 218-223.

Mathwick, C., Malhotra, N. \& Rigdon, E., 2001, 'Experiential value: Conceptualization, measurement and application in the catalog and Internet shopping environment' Journal of Retailing 77, 39-56. https://doi.org/10.1016/S0022-4359(00)00045-2

Mowen, J.C., 1988, 'Beyond consumer decision making', The Journal of Consumer Marketing 5(1), 15-25. https://doi.org/10.1108/eb008214

Murphy, L., Moscardo, G., Benckendorff, P. \& Pearce, P., 2011, 'Evaluating tourist satisfaction with retail experience in a typical tourist shopping villa', Journal of Retailing and Consumer Services 18, 302-310. https://doi.org/10.1016/ of Retailing and Consum

Muruganantham, G. \& Bhakat, R.S., 2013, 'A review of impulse buying behavior', International Journal of Marketing Studies 5(3), 149-160.

Ozer, L. \& Gultekin, B., 2015, 'Pre- and post-purchase stage in impulse buying: The role of mood and satisfaction', Journal of Retailing and Consumer Services 22, 71-76. https://doi.org/10.1016/j.jretconser.2014.10.004
Pallant, J., 2013, SPSS survival manual, 5th edn., McGraw Hill, Berkshire.

Pine, B.J. \& Gilmore, J.H., 1998, 'Welcome to the experience economy', Harvard Business Review 78(1), 97-105.

Pine, B.J. \& Gilmore, J.H., 2002, The experience is the marketing, Strategic Horizons LLP.

Pine, B.J. \& Gilmore, J.H., 2011, The experience economy, updated edition, Harvard Business School Publishing, Boston, MA.

Plevoets, B., Petermans, A. \& Van Cleempoel, K., 2010, 'Developing a theoretical framework for understanding (staged) authentic retail settings in relation to the current experience economy', Durling, D(Ed.,) DRS2010, 1-13.

Portas, M., 2010, From fast fashion to a more considered consumerism, pp. 1-3, viewed 10 August 2011, from http://www.urbanstudies.co.za/mar-future06. html.

Rook, D.W. \& Fisher, R.J., 1995, 'Normative influences on impulse buying behaviour', Journal of Consumer Research 22(3), 305-313. https://doi.org/ $10.1086 / 209452$

Rook, D.W. \& Gardner, M.P., 1993, 'In the mood: Impulse buying's affective antecedents', Research in Consumer Behaviour 6(7), 1-28.

Saad, M. \& Metawie, M., 2015, 'Store environment, personality factors and impulse buying behaviour in Egypt: The mediating roles of shop enjoyment and impulse buying tendencies', Journal of Business and Management Sciences 3(2), 69-77.

Schmitt, B., 1999, 'Experiential marketing', Journal of Marketing Management 15, 53-67. https://doi.org/10.1362/026725799784870496

Senthil, M., Chandrasekar, K.S. \& Selvabaskar, S., 2012, “"Experiential retailing” as a strategic tool for retail store differentiation and brand association - A conceptual approach', SIES Journal of Marketing 8(1), 92-102.

Sharma, P., Sivakumaran, B. \& Marshall, R., 2010, 'Impulse buying and variety seeking: A trait-correlates perspective', Journal of Business Research 63, 276-283. https:// doi.org/10.1016/j.jbusres.2009.03.013

Silvera, D.H., Lavack, A.M. \& Kropp, F., 2008, 'Impulse buying: The role of affect, social influence and wellbeing', Journal of Consumer Marketing 25(1), 23-33. https:// doi.org/10.1108/07363760810845381

Singh, S., Sinha, P.K. \& Mishra, H.G., 2013, “"Female consumers” recreational shopping experiences', International Research Journal of Business Studies 6(1), 1-11. https://doi.org/10.21632/irjbs.6.1.1-11

Solomon, M.R., 2007, Consumer behavior: Buying, having, and being, 7th edn., Pearson Prentice Hall, Upper Saddle River, NJ.

Stops, A., 2013, 'Experiential shopping motivates consumers in a changing retail landscape', Commercial Property News, viewed 08 December 2013, from https:// www.commercial-property-news/item/15302-experiential-shopping-motivatesconsumers-in-a-changing-retail-landscape.html

Tabachnick, B.G. \& Fidell, L.S., 2013, Using multivariate statistics, 6th edn., Pearson, Boston, MA.

Ungerer, L., 2014, Consumer behaviour: Global and Southern African perspective, Pearson, Cape Town.

Van Hamersveld, M. \& De Bont, C., 2007, Market research handbook, 5th edn., John Wiley and Sons Ltd, Upper Saddle River, NJ.

Verhoef, P.C., Lemon, K.N., Parasuraman, A., Roggeveen, A., Tsiros, M. \& Schlesinger L.A., 2009, 'Customer experience creation: Determinants, dynamics and management strategies', Journal of Retailing 85(1), 31-41. https://doi.org/ 10.1016/j.jretai.2008.11.001

Verplanken, B., Herabadi, A.G., Perry, J.A. \& Silvera, D.H., 2005, 'Consumer style and health: The role of impulsive buying in unhealthy eating', Psychology and Health 20(4), 429-441. https://doi.org/10.1080/08870440412331337084

Verplanken, B. \& Sato, A., 2011, 'The psychology of impulse buying: An integrative self-regulation approach', Journal of Consumer Policy 34, 197-210. https://doi. org/10.1007/s10603-011-9158-5

Virvilaite, R., Saladiene, V. \& Žvinklyte, J., 2011, 'The impact of external and internal stimuli on impulse purchasing', Economics and Management 2011(16), 13291331.

Walliman, N., 2005, Your research project, 2nd edn., Sage, London.

Youn, S. \& Faber, R.J., 2000, 'Impulse buying: Its relation to personality traits and cues', Advances in Consumer Research 27, 179-185.

Zander, K. \& Hamm, U., 2012, 'Information search behaviour and its determinants: The case of ethical attributes of organic food', International Journal of Consumer Studies 36, 307-316. https://doi.org/10.1111/j.1470-6431.2011.00998.x 